\title{
PHOTOSYNTHETIC RESPONSES OF Eucalyptus nitens AT INITIAL STAGES OF ROOT-ROT INFECTION
}

\author{
Luciasih Agustini ${ }^{1, *}$, Chris Beadle ${ }^{2}$, Karen Barry ${ }^{3}$ and Caroline Mohammed ${ }^{2,3}$ \\ ${ }^{1}$ Research and Development Center for Forest Conservation and Rehabilitation, Jl. Gunung Batu \\ No. 5 Bogor 16610, Indonesia \\ ${ }^{2}$ CSIRO Ecosystem Sciences, Private Bag 12, Hobart, Australia \\ ${ }^{3}$ Tasmanian Institute of Agriculture, University of Tasmania, Private Bag 98, Hobart, Australia
}

Received: 28 November 2013, Revised: 31 October 2014, Accepted: 2 November 2014

\begin{abstract}
PHOTOSYNTHETIC RESPONSES OF Eucalptus nitens AT INITIAL STAGES OF ROOT-ROT INFECTION. Root-rots are known to be latent diseases that may be present in plants for an extended period without any noticeable expression of symptoms above ground. Photosynthetic responses of Eucalyptus nitens saplings artificially inoculated with the root-rot pathogen, Armillaria luteobubalina were examined to characterize the initial stages of root-rot infection. This paper studies three photosynthetic parameters, i.e. photosystem II yield $\left(\mathrm{F}_{\mathrm{v}} / \mathrm{F}_{\mathrm{m}}\right)$, chlorophyll content and photosynthetic capacity $\left(\mathrm{A}_{\max }\right)$ for two strains of $A$. luteobubalina over a seven-month period. Root systems were either wounded or left intact before inoculation. A significant difference was observed in the $\mathrm{F}_{\mathrm{v}} / \mathrm{F}_{\mathrm{m}}$ ratio between the uninoculated control and inoculated saplings. Photosystem II yield was considered the most sensitive parameter for the early detection of root-rot disease. Chlorophyll content and $\mathrm{A}_{\max }$ decreased for all trees, including controls, during the period of the experiment, and most likely reflected host responses to seasonal change rather than treatment effects. Fungal re-isolations from symptomatic roots of inoculated trees confirmed the presence of A. luteobubalina. Findings from this preliminary trial indicated that there were detectable physiological changes associated with early infection of root-rot. However, to detect more widespread physiological changes an experiment of longer duration is needed.
\end{abstract}

Keywords: Eucalyptus nitens, artificial inoculation, chlorophyll content, photosynthetic rate, photosystem II yield, root disease

RESPON FOTOSINTESIS Eucalyptus nitens PADA TAHAP AWAL INFEKSI PENYAKIT BUSUK AKAR. Penyakit busuk akar merupakan penyakit yang bersifat laten yang dapat menginfeksi tanaman dalam jangka waktu lama tanpa menimbulkan gejala yang dapat diamati. Oleh karena itu, untuk mengetahui karakterperubahan fisiologis sebelum timbulnya gejala, telah dilakukan percobaan mengenai respon fotosintesis tanaman pada tahap awal infeksi penyakit busuk akar dengan cara menginokulasi anakan pobon Eucalyptus nitens dengan pathogen Armillaria luteobubalina. Inokulasi buatan dilakukan dengan menggunakan dua strain A. luteobubalina dan dua variasi perlakuan akar, yaitu : dilukai dan tidak dilukai. Respons fotosintesis diamati dengan cara mengukur tiga parameter fotosintesis, yaitu: efisiensi fotosistem II (Fv/Fm), kadar klorofil dan laju fotosintesis $\left(A_{\text {max }}\right.$. Pengamatan dilakukan selama tujuh bulan. Perbedaan yang signifikan ditunjuk.kan oleh data efisiensi fotosistem II (rasio Fv/Fm) antara kontrol dengan perlakuan-perlakuan lainnya. Fv/Fm merupakan parameter yang paling sensitif untuk mengindikasikan serangan awal penyakit busuk akar. Adapun parameter kadar klorofil dan laju fotosintesis $\left(A_{\text {max }}\right)$ menunjukkean nilai yang menurun baik pada tanaman kontrol maupun perlakuan. Perubahan nilai kedua parameter fotosintesis tersebut lebih ditentukan oleh perbedaan musim. Patogen A. luteobubalina berbasil diisolasi kembali dari akar E. nitens yang menunjukean penurunan respons fotosintesis. Hal tersebut menunjukkan bahwa penurunan respon fotosintesis berkaitan dengan adanya infeksi awal penyakit busuk akar. Namun diperlukan percobaan dengan waktu pengamatan yang lebih lama, agar perubahan respon fisiologis lainnya dapat terdeteksi.

Kata kunci: Eucalyptus nitens, inokulasi buatan, kadar klorofil, laju fotosintesis, efisiensi fotosistem II, busuk akar

*Corresponding author: luci_agustini@forda-mof.org; luciagustini@yahoo.com 


\section{INTRODUCTION}

Root-rots significantly reduce the productivity of important crops in tropical countries. For the majority of pathogens causing root-rot diseases, there is no clear indication of early infection (Mohammed, Rimbawanto \& Page, 2014). As such, methods for early detection of root-rot disease are important for the pulp, oil palm and rubber industries. Early detection might allow the implementation of effective remedial measures to combat root-rot diseases as long as associated costs are not prohibitive e.g. the removal of infected woody material and/or the targeted application of biocontrol agents in the area infected. However, early detection is difficult because individual trees can appear healthy above ground even when damage to the root system has become severe (Hadfield, Goheen, Filip, Schmitt \& Harvey, 1986; Farid, Lee, Maziah, Rosli \& Norwati, 2006). For example, in the case of basal stem rot in oil palm, foliar symptoms are only visually observed when the fungus has killed half of the basal stem (Mohammed et al., 2014).

Observation of thin crowns, growth reduction and/or foliage chlorosis have proven to be useful indicators for detecting infected tree for many root-rot diseases (Morrison, Williams \& Whitney, 1991; Omdal, Shaw \& Jacobi, 2004). At the leaf scale, root-rot diseases can induce many changes to the biochemical, physiological and structural properties of leaves, which may result in a range of visual symptoms including needle chlorosis, production of non-green metabolites, necrosis and desiccation. These changes can potentially be used for monitoring the health and condition of forests (Stone, Coops \& Culvenor, 2000, Luyssaert, Raitio, Vervaeke, Mertens \& Lust, 2002; GunthardtGoerg \& Vollenweider, 2007). For example, chlorophyll content has often been advocated as a sensitive indicator of many types of plant stress including drought, nutrient deficiency and diseases (Barry, Stone \& Mohammed, 2008). Determining leaf-level physiological responses of the host plants during the initial stage of root-rot infection could provide valuable information that may help with developing methods for the early detection of root-rot. To date, there has been little research on the effect of root disease on the host's physiology before the appearance of visual symptoms.

Photosynthetic capacity is useful parameter for monitoring these physiological changes. Stressful agents including fungal diseases can reduce the photosynthetic capacity due to their influence on one or more of the partial processes associated with photosynthesis (Dubey, 1997; Pinkard \& Mohammed, 2006). This influence may include decreased light-energy utilization, decreased chlorophyll content, the destruction of the chloroplast fine structure, degradation of photosystem (PS) II and alteration of biochemical processes (Sharma \& Hall, 1992; Sigh \& Dubey, 1995; Dubey, 1997; Chou, Bundock, Rolfe \& Scholes, 2000; Lopes \& Berger, 2001; Meyer, Saccardt, Rizza \& Genty, 2001; Berger, Papadopoulos, Schreiber, Kaiser \& Roitsch, 2004; Robert, Bancal, Nicolas \& Lannou, 2004; Berger, Sinha \& Roitsch, 2007).

The degree of inhibition of photosynthesis may be indicative of the aggressiveness of the pathogen (Guest \& Brown, 1997). Root pathogens, such as species of Armillaria, which occupy and alter the host's vascular tissue (Morrison et al., 1991) may influence the photosynthetic activity indirectly by affecting the pathways of water flow in the xylem. The impact of root-rot on photosynthetic activities may be similar to the disruptions caused by water stress that is associated with decreased stomatal conductance, a lowering of intercellular $\mathrm{CO}_{2}$, decreased chlorophyll level, changes in ultrastructure of chloroplasts, alteration in electron transport and decreased activity of the enzyme ribulose biphosphate carboxylase (Dubey, 1997).

Physiological aspects of plant-pathogen interactions have been well studied, especially for foliar diseases (Goicoechea, Aguirreolea, Cenoz \& Garcia-Mina, 2001; Bonfig, Schreiber, Gabler, Roitsch \& Berger, 2006; Pinkard \& Mohammed, 2006; Rodriguez-Moreno et al., 2007). In contrast, understanding the effects of root-rot diseases on plant physiology, especially in relation to hardwood trees, has received little 
attention. This paper observes physiological changes before the appearance of root-rot's visual symptoms.

We used the Eucalyptus nitens (H. Deane and Maiden) Maiden and Armillaria luteobubalina Watling and Kile model pathosystem to quantify the photosynthetic changes of the host plant in response to root-rot disease. Armillaria luteobubalina is a generalist pathogen that has approximately 88 hosts (Shaw \& Kile, 1991). This fungal species has been observed to cause root-rot in 3-year- and 6-year-old E.nitens plantations in Tasmania, Australia (Tim Wardlaw, personal communication). Findings from this pathosystem model will contribute valuable information about the potential to develop an early detection method of root diseases that are currently threatening the productivity of tropical plantation crops such as hardwoods, rubber and oil palm. In this experiment, the hypothesis that root infection will alter the processes associated with photosynthesis before the visual appearance of the disease symptoms is tested. We undertook a pot trial to characterize early physiological responses, (1) photosynthetic efficiency or photosystem (PS) II yield $\left(\mathrm{F}_{\mathrm{v}} / \mathrm{F}_{\mathrm{m}}\right.$ via chlorophyll fluorescence), (2) chlorophyll content, and (3) photosynthetic rate $\left(\mathrm{A}_{\max }\right)$ of $E$. nitens saplings to artificial inoculation with $A$. luteobubalina. Re-isolation of $A$. luteobubalina from symptomatic trees was also conducted in order to confirm whether the measured physiological changes were associated with the fungal pathogen infection.

\section{MATERIAL AND METHOD}

\section{A. Plants and Isolates}

Forty-two two-year-old E. nitens saplings were planted in $30-\mathrm{cm}$-diameter pots containing a potting-mix medium consisting of soil, sand, and pine-bark compost (1:1:1). A previous pilot study showed that this mixed-soil medium was suitable for maintaining the viability of the inoculum. The saplings were fertilised with $15 \mathrm{~g}$ of a slow-release fertilizer (Osmocote ${ }^{\circledR}$ ) and watered daily with drippers until saturated.

The fungal cultures were obtained by isolating from infected roots of an ornamental olive tree in the Hobart Royal Botanical Gardens, Australia (isolate strain 1) and a Cupressus sp. in Cascade Brewery Garden, Australia (isolate strain 2). Molecular analysis identified both isolates as A. luteobubalina having $98-100 \%$ sequence similarity with the described isolates in GenBank; there was a difference of seven nucleotides between isolates strains 1 and 2 (Agustini, 2010).

\section{B. Fungal Isolations}

Pure cultures of $A$. luteobubalina isolate strains 1 and 2 were obtained from sterilized infected root samples grown on $1 \%$ malt extract medium with the addition of selected antibiotics (MAT). Specifically, the MAT medium was prepared by autoclaving 1\% malt extract agar (MEA) for 30 min at $120^{\circ} \mathrm{C}$. Antibiotics (50 ppm penicillin, $50 \mathrm{ppm}$ streptomycin, $25 \mathrm{ppm}$ polymixin and $230 \mathrm{ppm}$ thiabendazole) were added to the autoclaved MEA during cooling (i.e. at $<60^{\circ} \mathrm{C}$ ). Root samples were surface-sterilised through a series of washings in different solutions, i.e. 2 min in tap water, 2-3 min in 20\% Chlorox ${ }^{\mathrm{TM}}$ (sodium hypochlorite solution), and three times in sterile water. Hyphae that grew from the root samples were sub-cultured onto $2 \% \mathrm{MEA}$ and incubated in the dark at $21^{\circ} \mathrm{C}$ for at least one month.

\section{Inoculum Preparation and Artificial Inoculation of Plant Material}

Branches harvested from young Eucalyptus globulus Labill. were prepared as inoculum rods using the method described by Mansilla et al. (2001), with some modification. The colonisation method involved inserting, under sterile conditions, branch segments $(5-6 \mathrm{~cm}$ in length and $1-2 \mathrm{~cm}$ in diameter) that had been autoclaved for $30 \mathrm{~min}$ at $120^{\circ} \mathrm{C}$ into a 200 $\mathrm{mL}$ tissue culture vessel (round autoclavable polycarbonate container with lid). This vessel contained $150 \mathrm{~mL}$ of sterile MAT medium. Additional MAT medium was added to ensure that the branch segments were completely submerged in agar. These branch segments were inoculated with $A$. luteobubalina by placing seven 


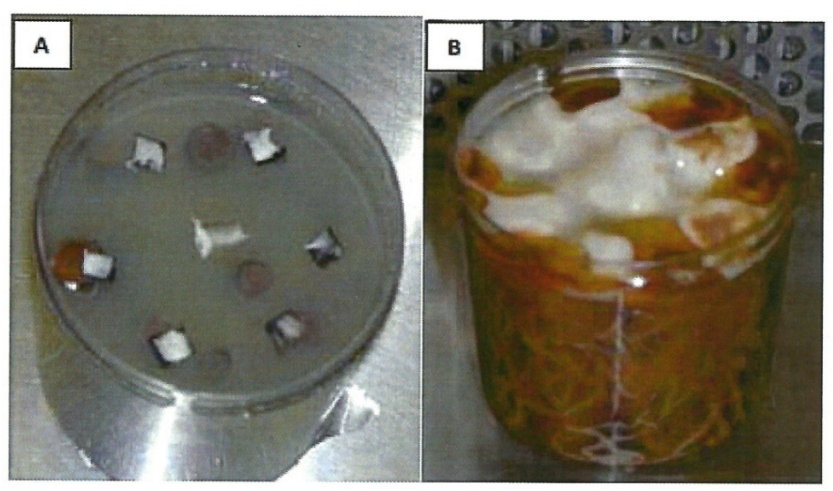

Figure 1. Pieces of agar with mycelia of $A$. luteobubalinaon the MAT media (A), Mycelial fans after incubation at $21^{\circ} \mathrm{C}$ for three months (B)

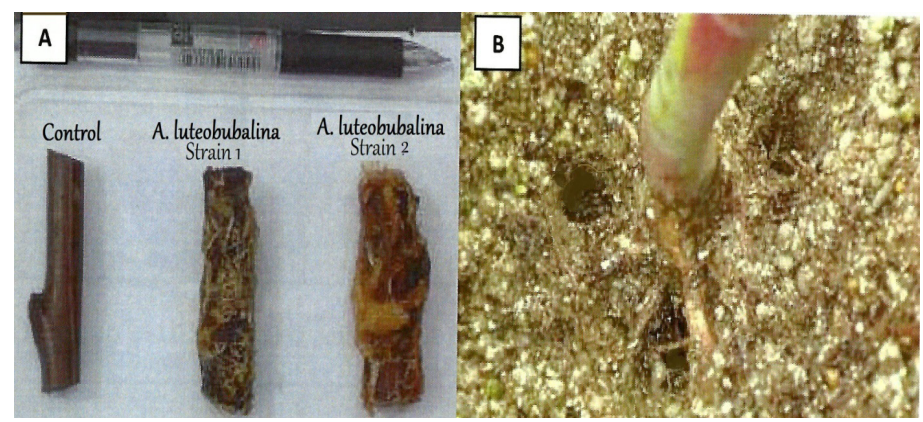

Figure 2. Inoculum rods (A), Inoculation sites: three holes close to the root collar (B)

colonised mycelial segments (approx. $1 \mathrm{~cm}^{2}$ ) onto the agar surface (Figure 1A). Each vessel was then closed, sealed with plastic film, and placed in the dark at $21-22^{\circ} \mathrm{C}$ for approximately three months until the E. globulus branches, hereafter referred to as inoculum rods, had been fully colonised with the mycelia and rhizomorphs of $A$. luteobubalina (Figure $1 \mathrm{~B}$ and $2 \mathrm{~A})$. Tissue culture vessels with uninoculated branch segments were also prepared to serve as controls.

Eucalyptus nitens saplings were inoculated by placing fully colonised inoculum rods (Figure 2A) into each pot adjacent to and just touching lateral roots in close proximity to the root collar (Figure 2B). The wounding treatment involved removing a small piece of bark (approx. 0.5-1 $\mathrm{cm}$ length) from the lateral roots using a Swiss Army knife.

\section{Experimental Layout}

A factorial design was applied in this greenhouse-based experiment. Six treatments were tested, including two physical treatments (i.e. unwounded and wounded host-root systems), and two different fungal treatments (i.e.Armillaria strain 1 and strain 2) and an uninoculated control. The physical treatments were applied in order to examine the ease of pathogen entry into the root tissue. The six treatments were: unwounded-control (UW-P0), wounded-control (W-P0), unwounded-isolate strain 1 (UW-P1), wounded-isolate strain 1 (W-P1), unwounded-isolate strain 2 (UW-P2), and wounded-isolate strain 2 (W-P2). Each treatment consisted of seven replications, resulting in a total of 42 saplings. The E. nitens saplings were arranged in a randomised within the block design.

\section{E. Physiological Measurements}

Photosynthetic capacity $\left(\mathrm{A}_{\max }\right)$ and maximum quantum yield of photosystem II yield $\left(\mathrm{F}_{\mathrm{v}} /\right.$ $\left.\mathrm{F}_{\mathrm{m}}\right)$ were assessed just prior to inoculation $\left(\mathrm{T}_{0}\right.$, 2 October 2008; Spring) and after the first symptoms were observed (T2, 29 April 2009; Autumn). During the seven months between $\mathrm{T}_{0}$ and $\mathrm{T}_{2}$, an intermediate measurement (T1, 30 January 2009; Summer) of $\mathrm{F}_{\mathrm{v}} / \mathrm{F}_{\mathrm{m}}$ was carried out to determine if there was any evidence 
of alterations in the plants' physiology prior to the appearance of the visual symptoms. Measurement frequency was decided based on the preliminary trial results which showed no significant differences in the above physiological variables between control and inoculated saplings over a six-month period. It suggested that extensive monitoring during the first six months after inoculation was not warranted.

Physiological assessments of $\mathrm{F}_{\mathrm{v}} / \mathrm{F}_{\mathrm{m}}, \mathrm{A}_{\max }$ and relative chlorophyll content were made on three fully-expanded leaves per sapling. The leaves were selected from the third or fourth leaf pair just behind the branch tip. All plants (42 saplings) were assessed. Chlorophyll fluorescence $\left(\mathrm{F}_{\mathrm{v}} / \mathrm{F}_{\mathrm{m}}\right)$ was measured pre-dawn using a chlorophyll fluorometer (OS-30p Opti-Science). Photosynthetic rate $\left(\mathrm{A}_{\max }\right)$ was quantified using a CIRAS infrared gas analyser (PP Systems, Herts, UK) with an artificial light source set to deliver $1500 \mu \mathrm{mol} \mathrm{m} \mathrm{m}^{-2} \mathrm{~s}^{-1}$ at the leaf surface and ambient $\mathrm{CO}_{2}$ concentration $(370-380 \mathrm{ppm})$.

A Minolta SPAD-502 chlorophyll meter (Konica-Minolta, Hong Kong, China) was used to obtain relative chlorophyll content. The SPAD was calibrated by directly measuring the chlorophyll concentration of thirty leaves. Fresh leaf discs (dry weight of each disc $0.020 \mathrm{~g}$ ) were extracted for chlorophyll content with a triple extraction method (Martin et al., 2007). Discs were ground in a mortar with approximately $50 \mu \mathrm{g} \mathrm{M}_{\mathrm{g}} \mathrm{CO}_{3}, 50 \mu \mathrm{g}$ washed, fine sand and a small volume of liquid nitrogen. Ground leaf material was extracted with three small volumes of 100\% cold acetone, and centrifuged for $3 \mathrm{~min}$. Absorbance was read at 470, 645, 663 and $710 \mathrm{~nm}$ with a Cary UV-VIS spectrophotometer (Varian Medical Systems, Inc., Palo Alto,CA, USA). Total chlorophyll $(\mathrm{Chl} a$ and $b$ ) was calculated using the equations of Lichtenthaler and Buschmann (2001). Using this data, a standard curve was created and the SPAD values converted to chlorophyll concentration $(\mu \mathrm{g} / \mathrm{g})$.

\section{F. Fungal Re-isolations}

All roots including those from inoculated and control plants were examined at the end of the experiment. Root balls were thoroughly washed and the inoculum rods were removed. Any symptoms and/or signs of infection were recorded and photographs taken. Fungal reisolations were undertaken from symptomatic roots exhibiting lesions and/or fungal mycelium (Figure 3). This was done to confirm that the causal agent associated with the deterioration of the plants was $A$. luteobubalina. The reisolations were carried out in the same way as the isolations described above.

Based on the presence or absence of fungal signs and/or root symptoms, four categories were established to describe the infection and root condition:

1. Positive infection by $A$. luteobubalina: as indicated the presence of either mycelial fans and/or lesion with white mycelia (early stage of mycelia fans) on the excavated root; fungal re-isolation was positive for A. luteobubalina.

2. Possible infection by $A$. luteobubalina: as indicated by the presence of a smallesion with white mycelia; fungal re-isolation was negative for $A$. luteobubalina.

3. Infection by un-inoculated fungi:

Neither mycelia fans nor white mycelia observed; only necrotic tissue or lesion present; fungal re-isolation confirmed fungi other than $A$. luteobubalina.

4. Uninfected: no fungal signs and/or root symptoms and roots appear healthy.

\section{G. Data Analysis}

Two-way analysis of variance (ANOVA) performed in XLSTAT2011® was used to analyse the physiological data. Duncan's multiple range tests were used to determine significant differences among treatments.

\section{RESULT AND DISCUSSION}

\section{A. Changes in Physiological Variables}

Physiological variables measured just before inoculation $\left(T_{0}\right)$ were not significantly different 


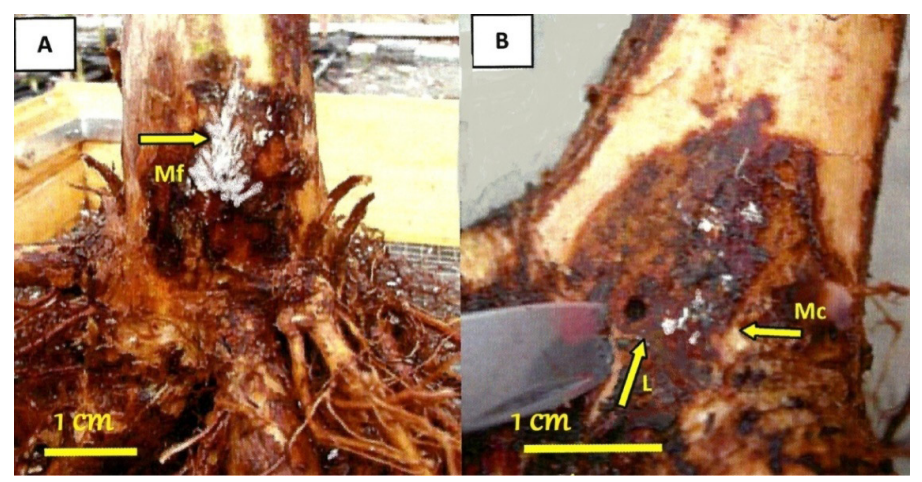

Figure 3. Mycelial fans (Mf) (A), lesion (L) and mycelia (Mc) on the root collar of infected Eucalyptus nitens saplings (B)

Table 1. Means \pm (SE) of the efficiency of PS II $\left(\mathrm{F}_{\mathrm{v}} / \mathrm{F}_{\mathrm{m}}\right)$, chlorophyll content and photosynthetic rate $\left(\mathrm{A}_{\max }\right)$ of E. nitens saplings inoculated with $A$. luteobubalina isolates over the period of observations at $\mathrm{T}_{0}, \mathrm{~T}_{1}\left(4\right.$ months after $\left.\mathrm{T}_{0}\right)$ and $\mathrm{T}_{2}\left(7\right.$ months after $\left.\mathrm{T}_{0}\right)$

\begin{tabular}{|c|c|c|c|}
\hline \multirow[b]{2}{*}{$\begin{array}{c}\text { Treatments / } \\
\text { Time }\end{array}$} & \multicolumn{3}{|c|}{ Physiological variables } \\
\hline & $\begin{array}{c}\text { Efficiency of PS II } \\
\mathrm{F}_{v} / \mathrm{F}_{m}\end{array}$ & $\begin{array}{c}\text { Chlorophyll content } \\
\mu \mathrm{g} / \mathrm{g}\end{array}$ & $\begin{array}{l}\text { Photosynthetic rate } \\
\left(A_{\max }\right) \mu \mathrm{mol} / \mathrm{m}^{2} / \mathrm{s}\end{array}$ \\
\hline UW-P0 / $\mathrm{T}_{0}$ & $0.78 \pm 0.01^{a}$ & $2918.8 \pm 231.1^{a}$ & $12.9 \pm 2.2^{a}$ \\
\hline $\mathrm{W}-\mathrm{P} 0 / \mathrm{T}_{0}$ & $0.77 \pm 0.02^{a}$ & $2772.1 \pm 168.8^{a}$ & $11.0 \pm 0.5^{\mathrm{a}}$ \\
\hline UW-P1 / $\mathrm{T}_{0}$ & $0.79 \pm 0.01^{a}$ & $2824.3 \pm 110.3^{a}$ & $11.6 \pm 1.5^{\mathrm{a}}$ \\
\hline $\mathrm{W}-\mathrm{P} 1 / \mathrm{T}_{0}{ }^{0}$ & $0.78 \pm 0.01^{a}$ & $2750.1 \pm 90.0^{a}$ & $13.5 \pm 0.8^{a}$ \\
\hline UW-P2 / $\mathrm{T}_{0}$ & $0.79 \pm 0.01^{a}$ & $2552.3 \pm 169.5^{a}$ & $13.0 \pm 0.8^{a}$ \\
\hline $\mathrm{W}-\mathrm{P} 2 / \mathrm{T}_{0}$ & $0.79 \pm 0.00^{\text {a }}$ & $2918.8 \pm 157.4^{a}$ & $13.9 \pm 1.1^{\mathrm{a}}$ \\
\hline UW-P0 / $\mathrm{T}_{1}$ & $0.83 \pm 0.01^{a}$ & NA & NA \\
\hline $\mathrm{W}-\mathrm{P} 0 / \mathrm{T}_{1}$ & $0.82 \pm 0.00^{a}$ & NA & NA \\
\hline UW-P1 / $\mathrm{T}_{1}$ & $0.81 \pm 0.01^{\text {a }}$ & NA & NA \\
\hline W-P1 / $\mathrm{T}_{1}{ }^{1}$ & $0.82 \pm 0.00^{a}$ & NA & NA \\
\hline UW-P2 / $\mathrm{T}_{1}$ & $0.82 \pm 0.00^{\text {a }}$ & NA & NA \\
\hline $\mathrm{W}-\mathrm{P} 2 / \mathrm{T}_{1}$ & $0.82 \pm 0.00^{a}$ & NA & NA \\
\hline UW-P0 / $\mathrm{T}_{2}$ & $0.81 \pm 0.01^{\text {a }}$ & $2117.7 \pm 119.6^{\mathrm{a}}$ & $10.0 \pm 0.4^{\mathrm{a}}$ \\
\hline $\mathrm{W}-\mathrm{P} 0 / \mathrm{T}_{2}$ & $0.76 \pm 0.01^{b}$ & $1939.0 \pm 133.9^{a b}$ & $8.5 \pm 0.7^{\mathrm{ab}}$ \\
\hline UW-P1 $/ T_{2}^{2}$ & $0.74 \pm 0.02^{b}$ & $1673.7 \pm 119.0^{b c}$ & $8.0 \pm 1.0^{\mathrm{ab}}$ \\
\hline $\mathrm{W}-\mathrm{P} 1 / \mathrm{T}_{2}{ }^{2}$ & $0.75 \pm 0.01^{\mathrm{b}}$ & $1490.7 \pm 81.3^{c}$ & $7.7 \pm 0.6^{\mathrm{b}}$ \\
\hline UW-P2 / $\mathrm{T}_{2}$ & $0.73 \pm 0.01^{b}$ & $1629.1 \pm 88.9^{b c}$ & $7.2 \pm 1.1^{\mathrm{b}}$ \\
\hline $\mathrm{W}-\mathrm{P} 2 / \mathrm{T}_{2}{ }^{2}$ & $0.75 \pm 0.01^{\mathrm{b}}$ & $1715.8 \pm 70.5^{\mathrm{bc}}$ & $8.4 \pm 0.5^{\mathrm{ab}}$ \\
\hline
\end{tabular}

Notes:

- The values followed by different letters in the same column are significant at $\alpha=0.05$, as determined by a Duncan's test-ANOVA for each variable at each time of observation.

- $\quad \mathrm{NA}=$ Not attempted

across treatments (Table 1). Three months after inoculation at intermediate assessment $\left(\mathrm{T}_{1}\right)$, photosynthetic efficiency of PS II ( $\mathrm{F}_{\mathrm{v}} /$ $\mathrm{F}_{\mathrm{m}}$ )was unaffected by treatments (Table 1$)$. The first physiological changes were detected seven months after inoculation $\left(T_{2}\right)$ when a significant difference in $\mathrm{F}_{\mathrm{v}} / \mathrm{F}_{\mathrm{m}}$ between the unwounded controls (UW-P0) and all other treatments 
Table 2. Change $( \pm \mathrm{SE})$ calculated as $\mathrm{T}_{2}-\mathrm{T}_{0}$ of physiological variables $\left(\mathrm{F}_{\mathrm{v}} / \mathrm{F}_{\mathrm{m}}\right.$, chlorophyll content and $\mathrm{A}_{\max }$ ) of E. nitens saplings inoculated with $A$. luteobubalina isolates.

\begin{tabular}{lccc}
\hline \multirow{3}{*}{ Treatments } & \multicolumn{3}{c}{ Photosynthetic variables } \\
\cline { 2 - 4 } & $\begin{array}{c}\text { Efficiency of PS II } \\
\left(F_{\mathrm{v}} / F_{\mathrm{m}}\right)\end{array}$ & $\begin{array}{c}\text { Chlorophyll content } \\
(\mu \mathrm{g} / \mathrm{g})\end{array}$ & $\begin{array}{c}\text { Photosynthetic rate } \\
\left(\boldsymbol{A}_{\max }\right) \mu \mathrm{mol} / \mathrm{m}^{2} / \mathrm{s}\end{array}$ \\
\hline UW-P0 & $0.03 \pm 0.01^{\mathrm{a}}$ & $-801.1 \pm 126.1^{\mathrm{a}}$ & $-3.0 \pm 1.9^{\mathrm{a}}$ \\
W-P0 & $0.00 \pm 0.02^{\mathrm{b}}$ & $-833.1 \pm 163.6^{\mathrm{b}}$ & $-2.5 \pm 0.8^{\mathrm{a}}$ \\
UW-P1 & $-0.05 \pm 0.03^{\mathrm{bc}}$ & $-1150.6 \pm 107.4^{\mathrm{ab}}$ & $-3.7 \pm 1.4^{\mathrm{a}}$ \\
W-P1 & $-0.03 \pm 0.01^{\mathrm{bc}}$ & $-1259.4 \pm 99.7^{\mathrm{b}}$ & $-5.8 \pm 0.9^{\mathrm{a}}$ \\
UW-P2 & $-0.06 \pm 0.02^{\mathrm{c}}$ & $-923.2 \pm 188.6^{\mathrm{ab}}$ & $-5.6 \pm 1.5^{\mathrm{a}}$ \\
W-P2 & $-0.04 \pm 0.01^{\mathrm{bc}}$ & $-1116.9 \pm 140.6^{\mathrm{ab}}$ & $-5.5 \pm 1.1^{\mathrm{a}^{\mathrm{b}}}$ \\
\hline
\end{tabular}

Note: The values followed by different letter in the same column are significant at $\alpha=0.05$, as determined by separate Duncan's test-ANOVA for each parameter at each time of observation.

was observed (Table 1). In particular, the $\mathrm{F}_{\mathrm{v}} /$ $\mathrm{F}_{\mathrm{m}}$ saplings in the unwounded-control (UWP0) treatment increased, while in the other treatments $\mathrm{F}_{\mathrm{v}} / \mathrm{F}_{\mathrm{m}}$ decreased; reductions in $\mathrm{F}_{\mathrm{v}} /$ $\mathrm{F}_{\mathrm{m}}$ were significantly greater in the inoculated (for both isolates and wound types) plants than in the UW-P0 treatment (Table 2).

Treatments effects on chlorophyll content (total $\mathrm{Chl} \mathrm{a}$ and $\mathrm{b}$ ) and Amax were more variable. At T2, there was a significant difference in chlorophyll content between inoculated (for both isolates and wound types) and UW-P0 plants (Table 1). Chlorophyll content decreased over the seven-month period of the experiment but, except for UW-P1 plants, there was no differences between inoculated and control treatments (Table 1). Photosynthetic capacity $\left(A_{\max }\right)$ decreased in all treatments during this period but there were no significant differences between treatments (Table 2).

Statistical tests show that the response of photosynthetic efficiency of PS II was affected by an interaction between time and treatments $($ F-ratio $=3.798, \mathrm{P}$-value $=0.005)$. For chlorophyll content and photosynthetic rate, the responses were more determined by sampling date (P-value $<0.0001)$.

Plant physiological changes associated with root-rot disease are not easy to detect. This is because diseases take time to develop before the plant expresses detectable physiological changes to the pathogen infection (Brown et al., 2012). This study found that E. nitens saplings grown under semi-controlled conditions required approximately seven months for developing the first detectable changes in physiological performance following artificial inoculation with $A$. luteobubalina (Table 1).

In this study, $\mathrm{F}_{\mathrm{v}} / \mathrm{F}_{\mathrm{m}}$ was shown to be the most sensitive physiological variable to detect stress caused by the root-rot pathogen; a significant reduction in $\mathrm{F}_{\mathrm{v}} / \mathrm{F}_{\mathrm{m}}$ in response to inoculation was observed seven months after treatment. Changes in $\mathrm{F}_{\mathrm{v}} / \mathrm{F}_{\mathrm{m}}$ have been widely used as a reliable diagnostic indicator of damage in response to various stresses such as extreme temperatures, and water and nutrient stress (Close \& Beadle, 2003; Epron, Dreyer \& Breda, 1992; Gamon \& Pearcy, 1989; Groom \& Baker 1992; He, Chee \& Goh, 1996; Valladares \& Pearcy, 1997). Since root-rot pathogens attack the vascular system of plants, responses to infection may be similar to those observed for drought stress. In drought-stressed plants, thylakoid membranes are the primary site of injury which leads to the decline of PS II activity (Dubey, 1997; Mutava, 2009). However, there was no evidence in this study that the decline in PS II activity was associated with parallel reductions in light-saturated photosynthetic rate $A_{\text {max }}$, but this may be because the reductions in $\mathrm{F}_{\mathrm{v}} / \mathrm{F}_{\mathrm{m}}$ were not yet of sufficient magnitude. Decreases of PS II activity under stress are associated with photoinhibition where free high energy radicals in the thylakoid membranes cause photo-oxidation of the chlorophyll 
(Havaux, 1992; Mutava, 2009). Differences between treatments in chlorophyll content at $\mathrm{T}_{2}$ in this experiment suggested that this may occur; however between treatment reductions in chlorophyll content between $\mathrm{T}_{0}$ and $\mathrm{T}_{2}$ were not significantly different.

While decreases in $A_{\max }$ between $T_{0}$ and $\mathrm{T}_{2}$ were not significant, it is probable that the reduced rate was a response to seasonal changes in light and temperature as the $\mathrm{T}_{0}$ measurement was done in mid-spring when the daily light exposure and temperature ranged between 3.1 to $32.8 \mathrm{MJ} / \mathrm{m}^{2}$ and 10.6 to $30.6^{\circ} \mathrm{C}$, respectively, while the $\mathrm{T}_{2}$ was in late autumn when the daily light exposure and temperature ranged between 2.3 to $19.0 \mathrm{MJ} / \mathrm{m}^{2}$ and 10.4 to $26.5^{\circ} \mathrm{C}$, respectively. Leaves growing in a high light environment attain greater $A_{\max }$ than leaves growing in a low light environment (DeJong \& Doyle, 1985). Reduced $A_{\max }$ can also be caused by reductions in seasonal temperatures (Battaglia, Beadleand \& Loughhead, 1996) and overnight frost (Davidson, Battaglia \& Close, 2004). Photosynthetic rates have shown to be closely related to chlorophyll content (Boardman, 1977; DeJong \& Doyle, 1985), and this is consistent with the reduced chlorophyll content observed in this experiment. Loss of chlorophyll content was also found in Pinus sylvestris as seasonal temperatures declined (Ottander, Campbell \& Oquis, 1995).

\section{B. Re-isolation from Infected Roots}

Root excavation showed that most of the inoculated saplings, both wounded and unwounded, were infected by $A$. luteobubalina (Table 3). Wounded saplings (W-P1 and W-P2) showed $100 \%$ and $85.7 \%$ infection of A. luteobubalina strain-1 and strain-2, respectively; unwounded ones (UW-P1 and UW-P2), both inoculated with $A$. luteobubalina strain-1 and strain-2 showed only $71.4 \%$ infection (Table 3); these results confirm that wounding tends to enhance the possibility of infection. Wounded saplings inoculated with both strains of $A$. luteobubalina showed a greater level of infection than unwounded saplings.

Table 3 also shows that $14.3 \%$ and $28.6 \%$ of the roots of wounded and unwounded control plants (W-P0 and UW-P0), respectively, were infected by other soil fungi. Identification of these confounding fungal isolates was beyond the scope of this study.

In the field, wounding as well as other factors, such as poor planting, poor drainage and soil compaction can contribute to the increased incidence and severity of Armillaria root disease (Hadfield et al., 1986). Intact outer bark may play an important role in protecting roots from invasion by pathogens (Wargo \& Harrington, 1991). Root grafts, breakage and associated insect feeding can potentially provide entry points for Armillaria and other root pathogens (Harrington, 1986; Rizzo \& Harrington, 1988; Whitney, 1961). However, Baumgartner and Rizzo (2006) found that wounding the root collar of grapevine rootstocks did not significantly increase the infection rate of Armillaria mellea in a greenhouse trial. This suggests that wounding can trigger host defence reactions

Table 3. Percentages of saplings for which pathogens were re-isolated from rootsin each of four categories.

\begin{tabular}{lcccc}
\hline \multirow{2}{*}{ Treatments } & \multicolumn{4}{c}{ Root condition } \\
\cline { 2 - 5 } & $\begin{array}{c}\text { Positively } \\
\text { infected }\end{array}$ & $\begin{array}{c}\text { Possibly } \\
\text { infected }\end{array}$ & $\begin{array}{c}\text { Infected by other } \\
\text { fungi }\end{array}$ & Uninfected \\
\hline UW-P & 0.0 & 0.0 & 28.6 & 71.7 \\
W-P $_{0}$ & 0.0 & 0.0 & 14.3 & 85.7 \\
UW-P $_{1}$ & 71.4 & 14.3 & 0.0 & 14.3 \\
W-P $_{1}$ & 100.0 & 0.00 & 0.0 & 0.0 \\
UW-P $_{2}$ & 71.4 & 28.6 & 0.0 & 0.0 \\
W-P $_{2}$ & 85.7 & 14.3 & 0.0 & 0.0 \\
\hline
\end{tabular}




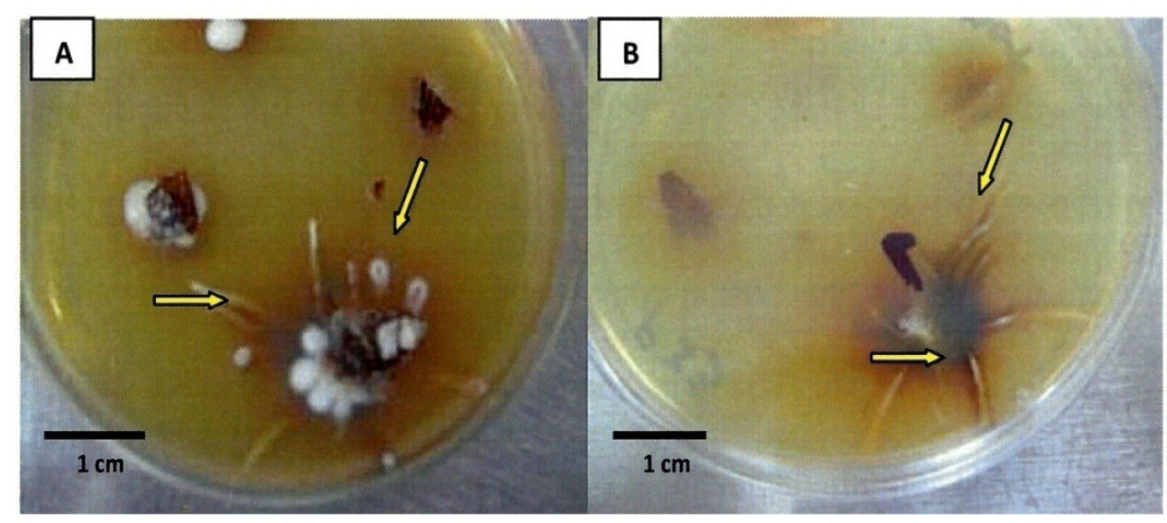

Figure 4. Re-isolated A.luteobubalina culture showing typical rhizomorphs (yellow arrows) Remarks: (A)surface; (B) inverted

(Eyles, Bonello, Ganley \& Mohammed, 2010), for example, the production of enzymes that function in lignin synthesis which leads to the reinforcement of the damaged cell wall (Baron \& Zambryski, 1995) and/or the release of lytic enzymes or toxic secondary metabolites that may limit hyphal penetration of the inner bark (Wargo \& Harrington, 1991). The possibility that wounding may have stimulated a defence reaction of the host in this study was not investigated.

Fungal infection was confirmed by the presence of mycelial fans and lesions on the root or root collar (Figure 3). Fungal cultures that had been isolated from the inoculated and symptomatic plants confirmed the presence of $A$. luteobubalina (Figure 4). The viability of the A. luteobubalina isolates on the E. globulus inoculum rods after being buried for seven months was low. Positive re-isolations of A. luteobubalina from these rods were obtained for three pots only and all were A. luteobubalina strain-1; re-isolations from inoculum rods carrying $A$. luteobubalina strain-2 were unsuccessful.

Similarly, there was a low level of successful re-isolations from the inoculum rods that had pseudosclerotial plates. Difficulties in reisolating from pseudosclerotial plates can be understood since they are an immobile/inactive phase of Armillaria and had probably developed in response to the occupation of the rods by decomposing soil fungi (Dowson, Rayner \&
Boddy, 1988).

This study confirmed the challenges of detecting the presence of root-rot disease during early infection. Among the physiological variables measured in this study, there was some evidence that at least one photosynthetic variable (i.e. $\mathrm{F}_{\mathrm{v}} / \mathrm{F}_{\mathrm{m}}$ ) may provide an early indicator of infection. Root and root collar examination remains the most reliable way to judge whether or not trees are infected. For Armillaria root disease, the production of characteristic mycelial fans can be also be used as a diagnostic feature.

\section{CONCLUSION}

Physiological responses to artificial infection with the root-rot pathogen, $A$. luteobubalina were examined in E. nitens saplings. Among the physiological variables measured, we found that $\mathrm{F} v / \mathrm{F} m$ was the most sensitive parameter for the early detection of root-rot disease. In particular, a significant difference in $\mathrm{F} v / \mathrm{Fm}$ between the unwounded control (UW-P0) and other treatments was observed. Chlorophyll content and $A_{\max }$ decreased for all trees, including controls during the seven months period and most likely reflected changes in season rather than treatment effects. Successful re-isolation of the root pathogen $A$. luteobubalina from inoculated symptomatic roots confirmed that the physiological changes were associated with the infection by this fungal pathogen. However, the functional changes that led to a reduction 
in PS II efficiency in the inoculated saplings require further investigation. The finding from this study demonstrated that several months may be required following infection before any physiological changes can be detected. Rootrot is known to be a latent disease that may be present in plants for an extended period without any noticeable expression of symptoms. Longer periods of observation than were possible in this experiment are recommended for further research with a similar focus of interest.

\section{ACKNOWLEDGEMENT}

This study was financially supported by Australian Centre for International Agricultural Research (ACIAR) through the John Allwright Fellowship and Project FST/2003/048. We thank Dr. Morag Glen, for assistance with molecular analysis and Dr. Alieta Eyles for assistance with physiological analysis and revision on an earlier draft of the manuscript. Support from numerous staff in CSIRO Ecosystem Sciences is much appreciated.

\section{REFERENCES}

Agustini, L. (2010). Signs and symptoms of root rot in Eucalyptus pellita plantations in Indonesia (Thesis). University of Tasmania. Retrieved from http://ecite.utas.edu.au/rmdb/ ecite/q/ecite_view_author/21767

Baron, C., \& Zambryski, P.C. (1995). The plant response in pathogenesis, symbiosis and wounding: variation on a common theme? Annual Review of Genetics, 29, 107-129.

Barry, K.M., Stone, C., \& Mohammed, C.L. (2008). Crown-scale evaluation of spectral indices for defoliated and discolouredeucalypts. Int. J. Remote Sens, 29, 47-69.

Battaglia, M., Beadleand, C., \& Loughhead, S. (1996). Photosynthetic temperature responses of Eucalyptus globulus and Eucalyptus nitens. Tree Physiology, 29, 81-89.

Baumgartner, K., \& Rizzo, D.M. (2006). Relative resistance of grapevine rootstocks to Armillaria root disease. Journal of Ecology \& Viticulture, 57, 408-414.

Beadle, C. (2000). Physiology of eucalypts in relation to disease. In P.J. Keane, G.A. Kile, P.D. Podge, \& B.N. Browns (Eds.), Diseases and Pathogens of
Eucalyptus (pp. 61-70). Collingwood: CSIRO Publishing.

Berger, S., Papadopoulos, M., Schreiber, U., Kaiser, W., \& Roitsch, T. (2004). Complex regulation of gene expression, photosynthesis and sugar level by pathogen infection in tomato. Physiologia Plantarum, 122, 419-428.

Berger, S., Sinha, A.K., \& Roitsch, T. (2007). Plant physiology meets phytopathology: plant primary metabolism and plant-pathogen interaction. Journal of Experimental Botany, 58, 4019-4026.

Boardman, N.K. (1977). Comparative photosynthesis of sun and shade plants. Annual Review of Plant Physiology, 28, 355-377.

Bonfig, K.B., Schreiber, U., Gabler, A., Roitsch, T., \& Berger, S. (2006). Infection with virulent and avirulent $P$. syringae strains differentially affects photosynthesis and sink metabolism in Arabidobsis leaves. Planta, 225, 2006, 1-12. doi:10.1007/s00425-006-0303-3.

Brown, N.A., Antoniw, J., \& Hammond-Kosack, K.Z. (2012). The predicted secretome of the plant pathogenic fungus Fusarium graminearum: A refined comparative analysis. PLos ONE, 7, 4, e33731. doi:10.1371/journal. pone. 0033731 .

Chou, H., Bundock, N., Rolfe, S., \& Scholes, J. (2000). Infection of Arabidopsis thaliana leaves with Albugo candida (white blister rust) causes a reprogramming of host metabolism. Mol. Plant Pathol, 1, 99-113.

Close, D.C., \& Beadle, C.L. (2003). Chillingdependent photoinhibition, nutrition and growth analysis of Eucalyptus nitens seedlings during establishment. Tree Physiology, 23, 217-226.

Davidson, N.J., Battaglia, M., \& Close, D.C. (2004). Photosynthetic responses to overnight frost in Eucalptus nitens and E. globulus. Trees, 18, 245-252.

DeJong, T.M., \& Doyle, J.F. (1985). Seasonal relationships between leaf nitrogen content (photosynthetic capacity) and leaf canopy light exposure in peach (Prunus persica). Plant, Cell and Environment, 8, 701-706.

Dowson, C.G., Rayner, A.D.M., \& Boddy, L. (1988). he form and outcome of mycelial interactions involving cord-forming decomposer basidiomycetes in homogeneous and heterogeneous environments. New Phytologist, 109, 423-432. 
Dubey, R. (1997). Photosynthesis in plants under stressful condition. In M. Pessarakli (Ed.), Handbook of photosynthesis (p. 1027). New York: Marcel-Dekker Inc.

Epron, D., Dreyer, E., \& Breda, N. (1992). Photosynthesis of oak trees (Quercus petraea (Matt) Liebl.) during drought stress under field condition: Diurnal course of net $\mathrm{CO}_{2}$ assimilation and photochemical efficiency of photosystem II. Plant, Cell and Environment, 15, 809-820.

Eyles, A., Bonello, P., Ganley, R., \& Mohammed, C. (2010). Induced resistance to pests and pathogens in trees. New Phytologist, 185, 893 908.

Farid, A.M., Lee, S.S., Maziah, Z., Rosli, H., \& Norwati, M. (2006). Root rot in tree species other than Acacia. In K. Potter, A. Rimbawanto, \& C. Beadle (Eds.), Heart rot and root rot in tropical Acacia plantations. Proceedings of a workshop beld in Yogyakarta, Indonesia, 7-9 February 2006 (ACLAR Proceedings No. 124) (pp. 60-66).

Gamon, J. A., \& Pearcy, R.W. (1989). Leaf movement, stress avoidance and photosynthesis in Vitis californica. Oecologia, 79, 475-481.

Goicoechea, N., Aguirreolea, J., Cenoz, S., \& Garcia-Mina, J. M. (2001). Gas exchange and flowering in Verticillium-wilted pepper plants. J. Phytopatho, 149, 281-286.

Groom, Q.J., \& Baker, N. R. (1992). Analysis of light-induced depression of photosynthesis in leaves of wheat crop during the winter. Plant Physiology, 100, 1217-1223.

Guest, D., \& Brown, J. (1997). Infection process. In J. F. Brown \& H. J. Olsen (Eds.), Plantpathogens and plant diseases (pp. 245-262). Armidale, Australia: University of New England.

Gunthardt-Goerg, M.S., \& Vollenweider, P. (2007). Linking stress with macroscopic and microscopic leaf response in trees: New diagnostic perspectives. Environmental Pollution, 147, 467-488.

Hadfield, J.S., Goheen, D.J., Filip, G.M., Schmitt, C.L., \& Harvey, R.D. (1986). Root diseases in Oregon and Washington conifers (R6FPM-250-86). Washington D.C.: USDA Forest Service, PNW Region.

Harrington, T.C. (1986). Growth decline of windexposed red spruce and balsam fir in the White Mountains. Canadian Journal of Forest Research, 16, 232-238.
Havaux, M. (1992). Stress tolerance of photosystem II in vivo: antagonistic effects of water, heat and photoinhibition stresses. Plant Physiology, 100, 424-432.

He, J., Chee, C.W., \& Goh, C.J. (1996). Photoinhibition of Heliconia under natural tropical condition: The importance of leaf orientation for light interception and leaf temperature. Plant, Cell and Environment, 19, 1238-1248.

Lichtenthaler, H.K., \& Buschmann, C. (2001). Chlorophylls and carotenoids. Measurements and characterisation by UV-VIS. Current Protocols in Food Analytical Chemistry (pp. F4.3.1-F4.3.8). Madison: John Wiley \& Sons.

Lopes, D.B., \& Berger, R.D. (2001). The effects of rust and anthracnose on the photosynthetic competence of diseased bean leaves. Phytopathology, 91, 212-220.

Luyssaert, S., Raitio, H., Vervaeke, P., Mertens, J., \& Lust, N. (2002). Sampling procedure for the foliar analysis of deciduous trees. J. Environ. Monit, 4, 858-864.

Mansilla, J.P., Aguin, O., \& Sainz, M.J. (2001). A fast method for production of Armillaria inoculum. Mycologia. Mycologia, 93, 612-615.

Martin, I., Alonso, N., Lopez, M.C., Prieto, M., Cadahia, C., \& Eymar, E. (2007). Estimation of leaf, root, and sap Nitrogen status using the SPAD-502 chlorophyll meter for ornamental shrubs. Communication in Soil Science and Plant Analysis, 38, 1785-1803.

Meyer, S., Saccardt, A.K., Rizza, F., \& Genty., B. (2001). Inhibition of photosynthesis by Colletotrichum lindemuthianum in bean determined by chlorophyll fluorescence imaging. Plant Cell Environ., 24, 947-955.

Mohammed, C., Rimbawanto, A., \& Page, D. (2014). Management of basidiomycete rootand stem-rot diseases in oil palm, rubber and tropical hardwood plantation crops. For. Pathol, In press.

Morrison, D.J., Williams, R. E., \& Whitney, R.D. (1991). Infection, disease development, diagnosis, and detection. In C. G. Shawn III \& G. . Kile (Eds.), Armillaria root disease (Agricultural Handbook No.691) (pp. 62-75). Washington D.C.: USDA Forest Service.

Mutava, R. N. (2009). Charachterization of grain sorghum for physiological and yield traits associated with drought tolerance (thesis). Kansas State University, USA. 
Omdal, D. W., Shaw III, C. G., \& Jacobi, W. R. (2004). Symptom expression in conifers infected with Armillaria ostoyae and Heterobasidion annosum. Can. J. For. Res., 34, 1210-1219.

Ottander, C., Campbell, D., \& Oquis, G. (2004). Seasonal changes in photosystem II organisation and pigment composition in Pinus sylvestris. Plant, Cell and Environment, 197, 176-183.

Pinkard, E.A., \& Mohammed., C.L. (2006). Photosynthesis of Eucalyptus globulus with Mycosphaerella leaf disease. New Phytologist, 170, 119-127.

Rizzo, D.M., \& Harrington, T.C. (1988). Root movement and root damage of red spruce and balsam fir on subalpine sites in the White Mountains, New Hampshire. Canadian Journal of Forest Research, 18, 991-1001.

Robert, C., Bancal, M., Nicolas, P., \& Lannou, C.B.N. (2004). Analysis and modelling of effects of leaf rust and Septoria tritici blotch on wheat growth. Journal of Experimental Botany, 55, 1079-1094.

Rodriguez-Moreno, L., Pineda, M., Soukupova, J., Macho, A.P., Beuzon, C.R., Baron, M., \& Ramos, C. (2007). Early detection of bean infection by Pseudomonas syringae in asymtomatic leaf areas using chlorophyll fluorescence imaging. Photosynth. Res. doi:10.1007/s11120-007-9278-6.
Sharma, P.K., \& Hall, D. (1992). Changes in carotenoid composition and photosynthesis in sorghum under high light and salt stress. $J$. Plant Physiol, 140, 661-666.

Shaw III, C.G., \& Kile, G.A. (Eds.). (1991). Armillaria root disease (Agricultural Handbook No. 691) (p. 233). Washington D.C.: USDA Forest Service.

Sigh, A.K., \& Dubey, R.S. (1995). Changes in chlorophyll a\&b contents and activities of photosystem $1 \& 2$ in rice seedlings induced by NaCl. Photosynthetic, 31, 489-499.

Stone, C., Coops, N., \& Culvenor., D. (2000). Conceptual development of a Eucalypt Canopy Condition Index using high resolution spatial and spectral remote sensing imagery. Journal of Sustainable Forestry, 11, 23-45.

Valladares, F., \& Pearcy, R.W. (1997). Interaction between water stress, sun-shade acclimation, heat tolerance and photoinhibition in the sclerophyll Heteromeles arbutifolia. Plant, Cell and Environment, 20, 25-36.

Wargo, P.M., \& Harrington, T.C. (1991). Host stress and susceptibility. In S.I.C.G. \& G.A. Kile (Eds.), Armillaria root disease (Agricultural Handbook No. 691) (pp. 88-101). Washington D.C.: USDA Forest Service.

Whitney, R.D. (1961). Root wounds and associated root rots of white spruce. Forestry Chronicle, 37, 401-411. 